\title{
Comparison of Mass and Nutrient Dynamics of Coarse Woody Debris between Quercus serrata and Q. variabilis Stands in Yangpyeong
}

\author{
Kim, Raehyun, Yowhan Son ${ }^{\star}$ and Jaehong Hwang ${ }^{1}$ \\ Division of Environmental Science and Ecological Engineering, Korea University, Seoul 136-701, Korea \\ Institute of Natural Environment and Conservation, Korea University, Seoul 136-701, Korea
}

\begin{abstract}
Coarse woody debris (CWD, $\geq 5 \mathrm{~cm}$ in maximum diameter) is an important functional component, especially to nutrient cycling in forest ecosystems. To compare mass and nutrient dynamics of CWD in natural oak forests, a two-year study was conducted at Quercus serrata and Q. variabilis stands in Yangpyeong, Kyonggi Province. Total CWD (snag, stump, log and large branch) and annual decomposition mass (Mg/ha) were 1.9 and 0.4 for the $Q$. serrata stand and 7.5 and 0.5 for the $Q$. variabilis stand, respectively. Snags covered $72 \%$ of total CWD mass for the $Q$. variabilis stand and $42 \%$ for the $Q$. serrata stand. Most of CWD was classified into decay class 1 for both stands. CWD N and $P$ concentrations for the $Q$. variabilis stand significantly increased along decay class and sampling time, except for $P$ concentration in 2002. There were no differences in CWD N concentration for the $Q$. serrata stand along decay class and sampling time. However, CWD $P$ concentration decreased along sampling time. CWD N and $P$ contents $(\mathrm{kg} / \mathrm{ha})$ ranged from $3.5 \sim 4.7$ and $0.8 \sim 1.3$ for the $Q$. serrata stand to $22.8 \sim 23.6$ and $3.7 \sim 4.7$ for the $Q$. variabilis stand. Nitrogen and $P$ inputs $(\mathrm{kg} / \mathrm{ha} / \mathrm{yr})$ into mineral soil through the CWD decomposition were 0.7 and 0.3 for the $Q$. serrata stand and 1.6 and 0.3 for the $Q$. variabilis stand, respectively. The number of $C W D$ and decay rate were main factors influencing the difference in CWD mass and nutrient dynamics between both stands.
\end{abstract}

Key words : Coarse woody debris, Decay class, Decomposition, Mass, Nutrient, Quercus serrata, Quercus variabilis

\section{-INTRODUCTION}

A large portion of forest production is stored as woody materials, and most of them eventually returned to the forest ecosystems as coarse woody debris (CWD) resulting from tree death. CWD is important structural and functional components of forest ecosystems (Harmon et al. 1986), particularly to plant and animal habitats, nutrient cycling, water storage, productivity, and geomorphology for soil structure (Bowman et al. 2000, Harmon et al. 1986, Spies et al. 1988, Stevens 1997, Triska and Cromack 1980). Because of its great mass and slow decay rate, woody debris often plays an important role as long-term nutrients storage pool and, consequently, may decrease effects of disturbances on forest ecosystems.

Oak species (Quercus spp.) are extensively distributed in natural deciduous and mixed forests in Korea, and many investigators have studied the production and biomass allocation for the species (Choi and Park 1993, Kim and Jung 1985, Lee and Chung 1986, Park et al. 1996). Although research on mass and nutrient dynamics of CWD is important to the understanding of nutrient cycling in oak forest ecosystems, little is known about the dynamics of CWD in
Korea. The objectives of this study were to 1) examine mass and decay class of CWD and 2) measure nitrogen and phosphorus dynamics of CWD for Quercus serrata and Q. variabilis stands in Yangpyeong.

\section{MATERIALS AND METHODS}

\section{Study site}

This study was conducted at $Q$. serrata $\left(37^{\circ} 56^{\prime} 81.3^{\prime \prime} \mathrm{N}, 12\right.$

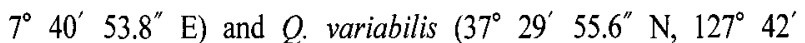
$6.5^{\prime \prime}$ E) stands in the Korea University Experimental Forest in Yangpyeong for two years. $Q$. serrata and $Q$. variabilis stands were selected within the natural oak forests and the stands were naturally regenerated after havesting Pinus densiflora-mixed hardwood forest (Kim et al. 1995). Characteristics of both stands were presented in Table 1. The understory vegetations were dominated by Styrax obassia Sieb. et Zucc., Rhus verniciflua Stockes, Lindera obtusiloba Bl., Fraxinus rhynchophylla Hance, and Symplocos chinensis for. pilosa Ohwi. for the Q. serrata stand and Q. mongolica Fisch., Lindera obtusiloba B1., Symplocos chinensis Miquel, and Corylus heterophylla Fisch. for the Q. variabilis stand. Mean January and July

\footnotetext{
* Correspónding author; Phone: 82-2-3290-3015, Fax: 82-2-928-0842, e-mail: yson@korea.ac.kr
} 
temperatures $\left({ }^{\circ} \mathrm{C}\right)$ of the last 10 years were -3.5 and 24.9 , respectively, and mean annual precipitation was $1316 \mathrm{~mm}$ (KMA, 1992 2003). The soil types were slightly dry brown forest soil (Chung 1986).

\section{Field work}

In the late May 2002, five $10 \mathrm{~m} \times 10 \mathrm{~m}$ plots were established within each stand. All CWD (snag, stump, log and large branch) with diameters $\geq 5 \mathrm{~cm}$ at break point in the plots were surveyed. Species, decay class, position, length and diameter were recorded for each CWD. All CWD were classified into five decay classes according to Sollins (1982) and Sollins et al. (1987). To assess the CWD volume, the length and diameter (both ends and the middle) were measured using digital calipers or diameter tape. Mean length was used in calculating CWD volume when the ends were not cut parallel. CWD length was measured to the nearest $0.1 \mathrm{~cm}$ and the total length of CWD suspended off the ground was measured to the nearest $0.1 \mathrm{~m}$. The maximum and minimum diameters were measured at each point to calculate the mean diameter. When CWD extended to the outside of the plot, the portion within the plot was measured. The height of snag was estimated using clinometers.

Total volume of CWD was calculated using Newton's formula (Harmon and Sexton 1996),

$$
V=L\left(A_{b}+4 A_{m}+A_{t}\right) / 6
$$

where $V$ is the volume, $L$ is the length; $A_{b}, A_{m}$, and $A_{t}$ are the area of the base, midpoint, and top of the CWD, respectively.

In case of snag, the volume was estimated using the following equation (Whitmore 1984).

$$
\mathrm{V}=\text { basal area } \times \text { height } \times 0.5
$$

To measure initial density and nutrient concentrations, a cross section (more than $10 \mathrm{~cm}$ thick) was executed at the end of each CWD (Harmon et al. 1999). Portions of the cross section with large knots were avoided. If a cross section was too decayed to be transported to the laboratory, the area of sample base was drawn on OHP film before cutting to estimate its volume on the spot (Sollins 1982). All cross sections were wrapped in plastic bags, returned to the laboratory, and stored at $-2^{\circ} \mathrm{C}$ until they were analyzed. Second cross sections were performed at a point of the first cut in late May, 2003.

\section{Laboratory work}

To measure initial density of cross section, diameters at 3 points (maximum and minimum diameter at both ends and middle) and mean longitudinal thickness $(\mathrm{ca} .10 \mathrm{~cm}$ ) for each cross section were measured by digital caliper in the laboratory. To measure the green weight of cross section, moss, fungus, litter, and mineral soil particles attached to the surface were removed using knife and brush. After measuring the weight, the cross sections were washed. To avoid leaching of soluble components, washing procedure was performed for 5 minutes and then the samples were dried at $55^{\circ} \mathrm{C}$ to a constant mass and weighed. Density was calculated by ovendry weight over green volume, and used in converting CWD volume into mass. Dry cross sections were ground to pass a No. 20 mesh and digested on block digestor (BD-46, Lachat Instruments, WI, USA), followed by analysis of total $\mathrm{N}$ and $\mathrm{P}$ concentrations using an Automated Ion Anayzer (Quick Chem AE, Lachat Instruments, WI, USA).

\section{Statistical analysis}

Mean nutrient concentrations were compared by stand, decay class and sampling time using analysis of variance (GLM procedure). Duncan's multiple range test was used to separate means at a probability level of $5 \%$. All statistical analyses were carried out using the Statistical Analysis System (SAS 1988).

\section{RESUI_TS AND DISCUSSION}

\section{CWD mass}

Total CWD mass (Mg/ha) in 2002 and 2003 was 1.9 and 1.5 for

\begin{tabular}{|c|c|c|c|c|c|c|c|}
\hline \multirow{3}{*}{ Stands } & \multirow{3}{*}{ Aspect } & \multirow{3}{*}{$\begin{array}{l}\text { Slope } \\
\left(^{\circ}\right)\end{array}$} & Height (m) & $\mathrm{DBH}(\mathrm{cm})$ & \multirow{3}{*}{$\begin{array}{c}\text { Basal a ea } \\
\left(\mathrm{m}^{2} / \mathrm{ha}\right)\end{array}$} & \multirow{3}{*}{$\begin{array}{c}\text { Stand density } \\
\text { (No./ha) }\end{array}$} & \multirow{3}{*}{ Age } \\
\hline & & & & & & & \\
\hline & & & & & & & \\
\hline \multirow{2}{*}{ Q. serrata } & \multirow{2}{*}{ ES } & \multirow{2}{*}{30} & $6.0 \sim 21.0$ & $6.5 \sim 29.5$ & \multirow{2}{*}{38.4} & \multirow{2}{*}{617} & \multirow{2}{*}{$25 \sim 30$} \\
\hline & & & 13.8 & 15.2 & & & \\
\hline \multirow{2}{*}{ Q. variabilis } & \multirow{2}{*}{ SW } & \multirow{2}{*}{40} & $7.0 \sim 22.0$ & $7.0 \sim 35.5$ & \multirow{2}{*}{56.0} & \multirow{2}{*}{510} & \multirow{2}{*}{$35 \sim 40$} \\
\hline & & & 16.1 & 17.6 & & & \\
\hline
\end{tabular}

Table 1. Stand characteristics of the study site 
the Q. serrata stand, and 7.5 and 7.0 for the $Q$. variabilis stand, respectively (Table 2 ). These values were lower than those for other temperate deciduous forests. For example, Kim (2003) and You and Kim (2002) reported that CWD mass ranged from 17.7 to 20.7 $\mathrm{Mg}$ /ha for natural deciduous forests in Kwangneung experimental forest. Harmon et al. (1986) also suggested that CWD mass was in the range of 11 to $38 \mathrm{Mg} / \mathrm{ha}$ for various temperate deciduous forests. Numerous studies reported differences in CWD mass according to site, management history, successional status of the stand, as well as stand moisture status (Harmon et al. 1986, Lambert et al. 1980, Spies et al. 1988).

CWD mass was approximately 4 times greater for the $Q$. variabilis stand than for the $Q$ serrata stand. This result might be related to the differences in the number of CWD and decay rate between both stands. It was generally noticed that decay rate of CWD was higher for $Q$. serrata than for $Q$. variabilis, although the decay resistance and their lignin content were similar for the two species (Korea Forest Research Institute 1994). Lower initial mean density $\left(0.35 \mathrm{~g} / \mathrm{cm}^{3}\right.$ for $Q$. serrata and $0.43 \mathrm{~g} / \mathrm{cm}^{3}$ for $Q$. variabilis $)$ and higher water absorption ability $(61.7 \%$ for $Q$ serrata and $46.4 \%$ for $Q$. variabilis) were another reasons for the higher decay rate for Q. serrata (Korea Forest Research Institute 1994).

CWD mass by decay class was shown in Fig. 1. Most of CWD mass was classified into decay class 1 . This was related to higher proportion of snag in total CWD mass in decay class $1(72 \%$ for $Q$. variabilis and $42 \%$ for $Q$. serrata) (Table 2 ). In the literature, CWD mass distribution among decay classes showed inconsistent patterns. For example, Spies et al. (1988) and Sturtevant et al. (1997) reported that the proportion of total mass in decay class 4 and 5 were highest in young stands and lowest in old stands. However, other investigators reported that CWD in decay class 3 and 4 were dominant in the old-growth stand (Fisk et al. 2002, Graham and Cromack 1982, Siitonen et al. 2000, Sollins et al. 1987).

\section{Nutrient concentrations}

Mean CWD N and P concentrations (\%) were 0.3 and 0.07 for the $Q$. serrata stand and 0.5 and 0.06 for the $Q$. variabilis stand in 2002. These values were close to those (only stem) for other Quer-
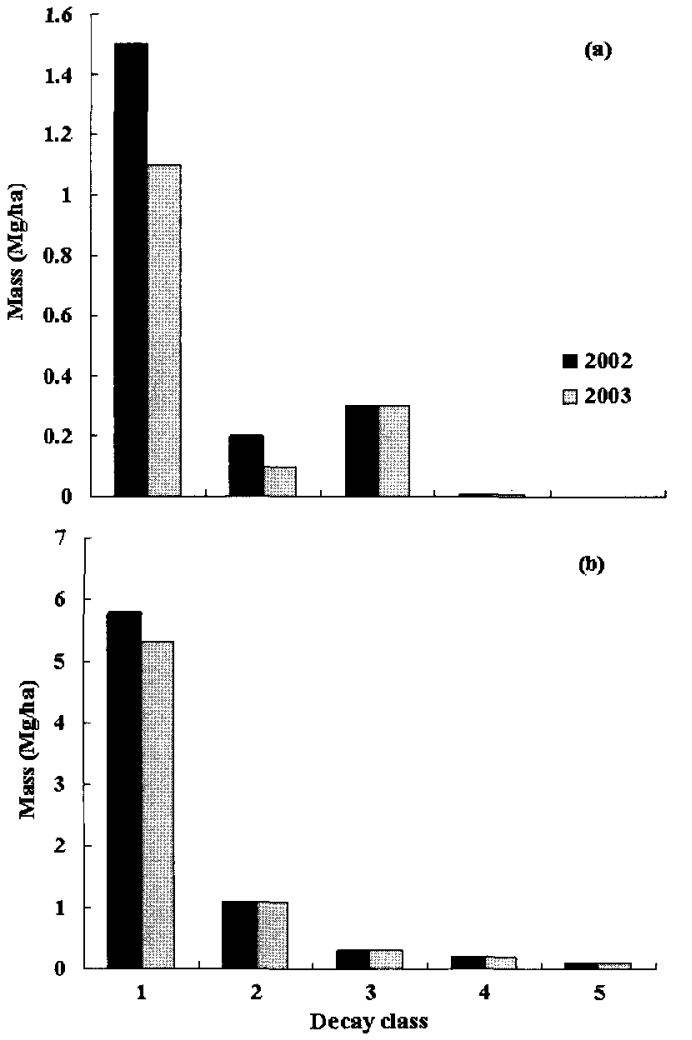

Fig. 1. Mass $(\mathrm{Mg} / \mathrm{ha})$ of coarse woody debris by decay class for $Q$ serrata (a) and Q. variabilis (b) stands in 2002 and 2003.

cus spp. with similar ages (Kwak and Kim 1992, Mun et al. 1977, Son et al. 2004). Mean CWD N concentration was significantly higher for the $Q$. variabilis stand than for the $Q$. serrata stand $(P$ $<0.0001$ ), although there was no significant difference in $P$ concentration between the two stands.

CWD $\mathrm{N}$ concentration (\%) of the $Q$. variabilis stand increased along decay class from $0.3 \sim 0.5$ in class 1 to 0.9 in class 5 , and there were significant differences among the decay classes and sampling times for the $Q$. variabilis stand (Fig. 2). It has been generally found that CWD $\mathrm{N}$ concentration increased with decay process (Busse 1994, Chueng and Brown 1995, Graham and Cromack 1982, Harmon et al. 1987, Holub et al. 2001, You and Kim 2002). Increases in CWD $\mathrm{N}$ concentration might be due to microbial or

Table 2. Number and mass $(\mathrm{Mg} / \mathrm{ha})$ of coarse woody debris for Q. serrata and Q. variabilis stands

\begin{tabular}{|c|c|c|c|c|c|c|c|c|c|c|}
\hline \multirow{3}{*}{ Stands } & \multicolumn{5}{|c|}{2002} & \multicolumn{5}{|c|}{2003} \\
\hline & \multirow{2}{*}{ No. of CWD } & \multicolumn{4}{|c|}{ Mass } & \multirow{2}{*}{ No. of CWD } & \multicolumn{4}{|c|}{ Mass } \\
\hline & & Snag & Stump & $\log$ & Total & & Snag & Stump & $\log$ & Total \\
\hline Q. serrata & 86 & 0.8 & 0.2 & 0.9 & 1.9 & 77 & 0.6 & 0.1 & 0.8 & 1.5 \\
\hline Q. variabilis & 31 & 5.4 & 0.3 & 1.8 & 7.5 & 28 & 5.0 & 0.3 & 1.7 & 7.0 \\
\hline
\end{tabular}


non-microbial $\mathrm{N}$ immobilization and addition of $\mathrm{N}$ by precipitation, dust deposit, and asymbiotic nitrogen fixation (Wei et al. 1997). Numerous investigators reported that $\mathbf{P}$ concentration also increased along decay class (Idol et al. 2001, Kim 2003, You and Kim 2002). Increase in CWD P concentration with decay class might be related to increased microbial demand for $\mathbf{P}$ in later decay classes (Holub et al. 2001). In addition, there is ample opportunity for movement of $\mathrm{P}$ into the wood from humus layer (Lambert et al. 1980). Because numerous CWD in decay class 4 and 5 was buried within the soil.

There were no differences in CWD $\mathrm{N}$ concentration with decay class and sampling time for the $Q$. serrata stand. In contrast, Kim (2003) reported that CWD N and P concentrations increased along decay class for the Q. serrata stand in the Kwangneung natural deciduous forest. The reason for this different result was probably due to the small number of CWD within decay class $2 \sim 4$.

\section{Nutrient contents}

Total CWD N content $(\mathrm{kg} / \mathrm{ha}$ ) was 3.5 for the $Q$. serrata stand and 22.8 for the $Q$. variabilis stand in 2002 . After one year, the CWD N content $(\mathrm{kg} / \mathrm{ha})$ increased to 4.7 for the $Q$. serrata stand and 23.6 for the $Q$. variabilis stand (Table 3). Although CWD N content for the $Q$. serrata stand was lower than other results, the value was within the range of $15 \sim 33 \mathrm{~kg} / \mathrm{ha}$ reported for other

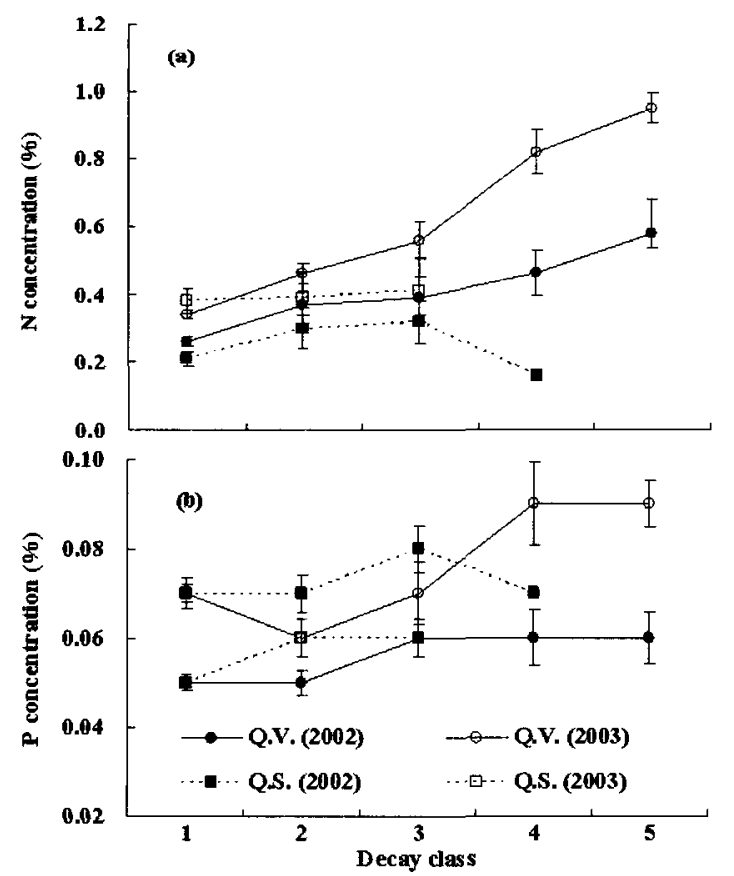

Fig. 2. Nitrogen (a) and phosphorus (b) concentrations (\%) of coarse woody debris by decay class for $Q$. serrata (Q.S.) and $Q$. variabilis (Q.V.) stands in 2002 and 2003. Vertical bars indicate standard error.
Table 3. Nitrogen and phosphorus contents $(\mathrm{kg} / \mathrm{ha})$ of coarse woody debris for $Q$. serrata and $Q$. variabilis stands in 2002 and 2003

\begin{tabular}{lrcrcc}
\hline \hline \multirow{2}{*}{ Stands } & \multicolumn{3}{c}{2002} & & \multicolumn{2}{c}{2003} \\
\cline { 2 - 3 } \cline { 5 - 6 } & $\mathrm{N}$ & $\mathrm{P}$ & & $\mathrm{N}$ & $\mathrm{P}$ \\
\hline Q. serrata & 3.53 & 1.33 & & 4.67 & 0.78 \\
Q. variabilis & 22.84 & 3.67 & & 23.55 & 4.68 \\
\hline
\end{tabular}

temperate forests (Harmon and Chen 1991, Kim 2003, You and Kim 2002). The different $N$ content was directly related to the higher $\mathrm{N}$ concentration and the greater CWD mass for the $Q$. variabilis stand. After one year total CWD P content ( $\mathrm{kg} / \mathrm{ha}$ ) decreased from 1.33 to 0.78 for the $Q$. serrata stand, while $\mathrm{P}$ content $(\mathrm{kg} / \mathrm{ha})$ increased from 3.67 to 4.68 for the $Q$. variabilis stand. These values were within the range of other temperate forests $(0.9 \sim 6.3 \mathrm{~kg} / \mathrm{ha})$ (Harmon and Chen 1991, Kim 2003, You and Kim 2002).

Annual $\mathrm{N}$ and $\mathrm{P}(\mathrm{kg} / \mathrm{ha} / \mathrm{yr})$ inputs to forest ecosystems through decomposing CWD were 0.7 and 0.3 for the $Q$. serrata stand and 1.6 and 0.3 for the $Q$. variabilis stand, respectively. These values were similar to the value for the other deciduous stand $(\mathrm{N}$ : 1.5 $\mathrm{kg} / \mathrm{ha} / \mathrm{yr}, \mathrm{P}: 0.1 \mathrm{~kg} / \mathrm{ha} / \mathrm{yr}$ ) (Kim 2003). Other studies reported that $\mathrm{N}$ and $P$ inputs $(\mathrm{kg} / \mathrm{ha} / \mathrm{yr})$ through litterfall were $20.5 \sim 61.0$ and $0.6 \sim 2.3$ for Qurecus spp. stands (Kim et al. 1997, 2003, Kwak and Kim 1992, Mun and Joo 1994, Mun and Pyo 1994). It appeared that CWD added relatively low amounts of nutrients to forest floor compared to litterfall. However, an important CWD role was that nutrients were released at slower rates from CWD than from litterfall (Grier 1978, Lambert et al. 1980, Sollins et al. 1987). Slow nutrient release allows nutrients to be retained within the ecosystem. In addition, a primary role of CWD was stabilizing nutrients after natural disturbances (Harmon and Chen 1991). It was difficult to draw a general conclusion on nutrient dynamics along time with only two years data. More detailed and long-term studies were needed to elucidate mass and nutrient dynamics of CWD in oak forest ecosystems.

\section{ACKNOWLEDGEMENTS}

We thank Y.C. Jun, J.O. Hwang, K.W. Seo, J.W. Koo, Y.H. Park and J.Y. Ban for their help in the field and laboratory work for this study. This research was supported by the Korea University Grant.

\section{LITERATURE CITED}

Bowman, J.C., D. Sleep, G.J. Forbes and M. Edwards. 2000. The 
association of small mammals with coarse woody debris at $\log$ and stand scales. For. Ecol. Manage. 129: 119-124.

Busse, M.D. 1994. Downed bole-wood decomposition in lodgepole pine forests of central Oregon. Soil Sci. Soc. Am. J. 58: 221227.

Choi, Y.C. and I.H. Park. 1993. Biomass and net production of a natural Quercus variabilis forests and a Populus alba $\times P$. glandulosa plantation at Mt. Mohu area in Chonnam. J. Kor. For. Soc. 82(2): 188-194 (in Korean with English abstract).

Chueng, N. and S. Brown. 1995. Decomposition of silver maple (Acer saccharinum L.) woody debris in a central Illinois bottomland forest. Wetlands 15(3): 232-241.

Chung, M.O. 1986. Studies on actual growth condition of main tree species in Yangpyong Experiment Forest. M.S. thesis. Korea University 39 pp. (in Korean with English abstract).

Fisk, M.C., D.R. Zark and T.R. Crow. 2002. Nitrogen storage and cycling in old-and second-growth northern hardwood forests. Ecology 83(1): 73-87.

Graham, R.L. and K. Cromack, Jr. 1982. Mass nutrient content and decay rate of dead boles in rain forests of Olympic National Park. Can. J. For. Res. 30: 1489-1493.

Grier, C.C. 1978. A Tsuga heterophylla-Picea sitckensis ecosystem of coastal Oregon: decomposition and nutrient balances of fallen logs. Can. J. For. Res. 8: 198-206.

Harmon, M.E. and H. Chen. 1991. Coarse woody debris dynamics in two old-growth ecosystems. BioScience 41(9): 604-610.

Harmon, M.E. and J. Sexton. 1996. Guidelines for measurements of woody detritus in forest ecosystems. US LTER Network Office Publication No. 20.

Harmon, M.E., K. Cromack Jr. and B.G. Smith. 1987. Coarse woody debris in mixed-conifer forests, Sequoia National Park, California. Can. J. For. Res. 17: 1265-1272.

Harmon, M.E., K.J. Nadelhoffer and J.M. Blair. 1999. Measuring decomposition, nutrient tumover, and stores in plant litter. In G.P. Robertson, D.C. Cloeman, C.S. Bledsoe and P. Sollins (eds.). Standard Soil Methods for Long-Term Ecological Research. Oxford University Press. pp. 202-240.

Harmon, M.E., J.F. Franklin, F.J. Swanson, P. Sollins, S.V. Gregory, J.D. Lattin, N.H. Anderson, S.P. Cline, N.G. Aumen, J.R. Sedell, G.W. Lienkamper, K. Cromack Jr, and K.W. Cummins. 1986. Ecology of coarse woody debris in temperate ecosystems. Adv. Ecol. Res. 15: 133-302.

Holub, S.M., J.D.H. Spears and K. Lajtha. 2001. A reanalysis of nutrient dynamics in coniferous coarse woody debris. Can. J. For. Res. 31: 1894-1902.

Idol, T.W., R.A. Figler, P.E. Pope and F. Ponder Jr. 2001. Characterization of coarse woody debris across a 100 year chronosequence of upland oak-hickory forests. For. Ecol. Manage. 149: 153-161.

Kim, R.H. 2003. Mass and nutrient dynamics of coarse woody debris in a natural deciduous forest of Kwangneung. M.S. thesis, Korea University. 45 pp. (in Korean with English abstract).

Kim, S.K. and J.Y. Jung. 1985. A study on the production structure and biomass productivity of Quercus variabilis natural forest. J. Kor. For. Soc. 70: 91-102 (in Korean with English abstract).

Kim, C.S., J.H. Lim and J.H. Shin. 2003. Nutrient dynamics in litterfall and decomposing leaf litter at the Gwangnung deciduous broad-leaved natural forest. Kor. J. Agri. For. Meteo. 5(2): $87-93$.

Kim, J.S., Y. Son and Z.S. Kim. 1995. Allometry and canopy dynamics of Pinus rigida, Larix leptolepis and Quercus serrata stands in Yangpyeong area. J. Kor. For. Soc. 84(2): 186-197.

Kim, C.S., K.S. Koo, Y.K. Kim, W.K. Lee, J.H. Jeong and H.S. Seo. 1997. Dynamics of litterfall and nutrient inputs in Quercus acutissima and Pinus koraiensis stands. FRI Journal of Forest Science 55: 13-18 (in Korean with English abstract).

KMA. 1992-2003. Annual climatological reports. Korea Meteological Administration. Seoul, Korea.

Korea Forest Research Institute. 1994. Wood properties and uses of the major tree species grown in Korea. KFRI Research Report 95: 166-211 (in Korean).

Kwak, Y.S. and J.H. Kim. 1992. Nutrient cyclings in Mongolian oak (Quercus mongolica) forest. Korean J. Ecol. 15: 35-46 (in Korean with English abstract).

Lambert, R.L., G.E. Lang and W.A. Reiners. 1980. Loss of mass and chemical change in decaying boles of a subalpine baisam fir forest. Ecology 61(6): 1460-1473.

Lee, D.S. and Y.G. Chung. 1986. Estimation of productivity for Quercus variabilis stand by forest environmental factors. J. Kor. For. Soc. 75: 1-18 (in Korean with English abstract).

Mun, H.T. and H.T. Joo. 1994. Litter production and decomposition in the Quercus acutissima and Pinus rigida forests. Korean J. Ecol. 17(3): 345-353 (in Korean with English abstract).

Mun, H.T. and J.H. Pyo. 1994. Dynamics of nutrient and chemical constituents during litter decomposition. Korean J. Ecol. 17(4): 501-511 (in Korean with English abstract).

Mun H.T., C.M. Kim and J.H. Kim. 1977. Distributions and cyclings of nitrogen, phosphorus and potassium in Korean alder and oak stands in Kwangju. Kor. J. Bot. 20: 109-118 (in Korean with English abstract).

Park, I.H., D.K. Lee, K.J. Lee and G.S. Moon. 1996. Growth, biomass and net production of Quercus species (I) - with reference to natural stands of Quercus variabilis, $Q$. acutissima, 
Q. dentata, and Q. mongolica in Kwangju, Kyonggi-Do. J. Kor. For. Soc. 85(1): 76-83 (in Korean with English abstract).

SAS. 1988. SAS/STAT User's Guide, 6.03 edition. SAS Institute, Cary, NC, USA.

Siitonen, J., P. Martikainen, P. Punttila and J. Rauh. 2000. Coarse woody debris and stand characteristics in mature managed and old-growth boreal mesic forests in southern Finland. For. Ecol. Manage. 128: 211-225.

Sollins, P. 1982. Input and decay of coarse woody debris in coniferous stands in western Oregon and Washington. Can. J. For. Res. 12: 18-28.

Sollins, P., S.P. Cline, T. Verhoeven, D. Sachs and G. Spycher. 1987. Patterns of log decay in old-growth Douglas-fir forests. Can. J. For. Res. 17: 1585-1595.

Son Y., I.H. Park, M.J. Yi, H.O. Jin, D.Y. Kim, R.H. Kim and J.O. Hwang. 2004. Biomass, production and nutrient distribution of a natural oak forest in central Korea. Ecol. Res. 19: 21-28.

Spies, T.A., J.F. Franklin and T.B. Thomas. 1988. Coarse woody debris in Douglas-fir forests of western Oregon and Washington. Ecology 69: 1689-1702.

Stevens, V. 1997. The ecological role of coarse woody debris: an overview of the ecological importance of CWD in B.C. forests.
Research Branch, B.C. Ministry of Forests, Victoria, B.C. Work. Pap. 30/1997.

Sturtevant, B.R., J.A. Bissonette, J.N. Long and D.W. Roberts. 1997. Coarse woody debris as a function of age, stand structure, and distribution in boreal Newfoundland. Ecol. Appl. 7(2): $702-712$.

Triska, F.J. and K. Cromack Jr. 1980. The role of wood debris in forests and streams. In R.H. Waring (ed.). Forests: Fresh Perspectives from Ecosystem Analysis. Oregon State Univ. Press, Corvallis. pp. 171-190.

Wei, X., J.P. Kimmins, K. Peel and O. Steen. 1997. Mass and nutrients in woody debris in harvested and wildfire-killed lodgepole pine forests in the central interior of British Columbia. Can. J. For. Res. 27: 148-155.

Whitmore, T.C. 1984. Tropical rain forests of the far east. Oxford University Press, Oxford, U.K.

You, Y.H. and J.H. Kim. 2002. Production of mass and nutrient content of decayirg boles in mature deciduous forest Kwangneung experimental forest station, Korea. Korean J. Ecol. 25(4): 261-265.

(Received April 6, 2004; Accepted April 14, 2004) 